\title{
Evaluation of the antibacterial and anticancer activities of some South African medicinal plants
}

\author{
Mary A Bisi-Johnson ${ }^{1 *}$, Chikwelu L Obi ${ }^{2}$, Toshio Hattori ${ }^{3}$, Yoshiteru Oshima ${ }^{4}$, Shenwei $\mathrm{Li}^{3}$, Learnmore Kambizi ${ }^{5}$, \\ Jacobus N Eloff', Sandeep D Vasaikar ${ }^{1}$
}

\begin{abstract}
Background: Several herbs are traditionally used in the treatment of a variety of ailments particularly in the rural areas of South Africa where herbal medicine is mainly the source of health care system. Many of these herbs have not been assessed for safety or toxicity to tissue or organs of the mammalian recipients.

Methods: This study evaluated the cytotoxicity of some medicinal plants used, inter alia, in the treatment of diarrhoea, and stomach disorders. Six selected medicinal plants were assessed for their antibacterial activities against ampicillin-resistant and kanamycin-resistant strains of Escherichia coli by the broth micro-dilution methods. The cytotoxicities of methanol extracts and fractions of the six selected plants were determined using a modified tetrazolium-based colorimetric assay (3-(4, 5-dimethylthiazol)-2, 5-diphenyl tetrazolium bromide (MTT) assay).
\end{abstract}

Results: The average minimum inhibitory concentration (MIC) values of the plants extracts ranged from $0.027 \mathrm{mg} /$ $\mathrm{ml}$ to $2.5 \mathrm{mg} / \mathrm{ml}$ after $24 \mathrm{~h}$ of incubation. Eucomis autumnalis and Cyathula uncinulata had the most significant biological activity with the least MIC values. The in vitro cytotoxicity assay on human hepatocarcinoma cell line (Huh-7) revealed that the methanol extract of $E$. autumnalis had the strongest cytotoxicity with $I_{50}$ of $7.8 \mu \mathrm{g} / \mathrm{ml}$. Ethyl acetate and butanol fractions of C. uncinulata, Hypoxis latifolia, E. autumnalis and Lantana camara had lower cytotoxic effects on the cancer cell lines tested with $I C_{50}$ values ranging from 24.8 to $44.1 \mu \mathrm{g} / \mathrm{ml}$; while all the fractions of Aloe arborescens and A. striatula had insignificant or no cytotoxic effects after $72 \mathrm{~h}$ of treatment.

Conclusions: Our results indicate that the methanol fraction of E. autumnalis had a profound cytotoxic effect even though it possessed very significant antibacterial activity. This puts a query on its safety and hence a call for caution in its usage, thus a product being natural is not tantamount to being entirely safe. However, the antibacterial activities and non-cytotoxic effects of $A$. arborescens and A. striatula validates their continuous usage in ethnomedicine.

\section{Background}

Various plants are used in the treatment of gastrointestinal related diseases. Several studies have documented reports on some herbs used in ethnotherapy of diarrhea, dysentery, vomiting, stomach cramps and other associated ailments [1-3]. Contrary to the belief of a large proportion of the populace that anything natural is safe, many commonly used herbs cause acute toxicity effects and in the long term may be toxic. The toxic effects may range from diarrhoea, hypersensitivity reactions, nausea or vomiting, to organ-targeted toxicity; immunotoxicity,

\footnotetext{
* Correspondence: jumokade@yahoo.co.uk

'Department of Medical Microbiology, Walter Sisulu University, Mthatha

5117, South Africa

Full list of author information is available at the end of the article
}

embryo/foetal and prenatal toxicity, mutagenicity/genotoxicity, hepatotoxicity, nephrotoxicity, presence of epileptogenic compounds, cardiac toxins, gastrointestinal toxins to carcinogenicity [4]. Other adverse effects of herbal medicines may include cardiovascular, neurological and dermatologic toxic effects. In the review by Luyckx and Naicker [5], it was stated that 'drug-induced nephrotoxicity reportedly contributes to up to $26 \%$ of cases of hospital-acquired acute kidney injury (AKI) and 18\% of cases of global community-acquired AKI ...' The review [5] further revealed that folk remedies account for up to $35 \%$ of cases of AKI in the developing world.

Many of the plants widely acclaimed to be of therapeutic values have not enjoyed vigorous assessments to gauge their safety. A number of cases of complications arising

\section{Biomed Central}


after the administration of medicinal herbs have been reported. Foyaca-Sibat and co-investigators described the case reports of two patients with neuromyotonia not associated with malignancies. The patients were reported to have developed acute renal failure while under treatment with herbal medications by their traditional healer in the former Transkei region of South Africa [6].

Other researchers have also identified medicinal plants with potential toxicity such as the extracts of Athrixia phylicoides DC. (Bush tea) [7]; and a flavonol glycoside from Bauhinia galpinii [8]. Genotoxicity and mutagenic effects in the Salmonella microsome assay have been reported in Crinum macowanii, Chaetacme aristata Planch. (Celastraceae), Plumbago auriculata Lam. (Plumbaginaceae), Catharanthus roseus (L.) G.Don. (Apocynaceae) and Ziziphus mucronata Willd. (Rhamnaceae) [9]. Additionally, Michellamine B-an alkaloid dimmers isolated from Ancistrocladus korupensis was inhibitory to several laboratory and clinical strains of $\mathrm{HIV}-1$, including the AZT resistant strain G910-6 and the pyridinone-resistant strain A17; as well as strains of HIV-2. However, the high toxicity of this compound to several human cell lines prevented its further evaluation [10]. Data on the cytotoxic assessments of herbs are very few compared with the huge number of plants acclaimed to have therapeutic values $[11,12]$. This study investigated the cytotoxic effects of Aloe arborescens, A. striatula, Cyathula uncinulata, Eucomis autumnalis, Hypoxis latifolia and Lantana camara commonly used in the treatment of gastrointestinal infections in the Oliver R. Tambo District Municipality (ORTDM), Eastern Cape Province, South Africa.

\section{Methods}

Plant material, extraction and fractionation

Fresh plant parts were collected in ORTDM, Eastern Cape Province, South Africa between July 2008 and
February 2010. The plants were identified in the Kei herbarium, Walter Sisulu University, South Africa where voucher specimens have been deposited. Information on the selected herbs are presented in Table 1[13-19]. The air-dried plant parts were extracted three times with methanol (Merck, Japan) and filtered using a Buchner funnel and Whatman No. 1 filter paper. The extracts were concentrated under reduced pressure at a temperature of $40^{\circ} \mathrm{C}$ using a rotating evaporator to yield methanol extract. The methanol extract was then suspended in deionised water and partitioned sequentially with Ethyl acetate and n-butanol. The fractions were concentrated under reduced pressure to yield the corresponding fractions and the remaining water fraction.

\section{Antibacterial assay}

The antibacterial assay was by the determination of minimum inhibitory concentration values of plant extracts and fractions against Gram negative bacteria strains. The broth dilution method was carried out in 96-well microtitre plates using ampicillin-resistant and kanamycin-resistant strains of Escherichia coli as the test organisms. A McFarland No1 standard suspension of bacteria inoculum was prepared in sterile Mueller Hinton Broth. Triplicate tests were performed in a series of two-fold dilutions of extract $(10 \mathrm{mg} / \mathrm{m} \ell)$ as previously described [20]. Kanamycin was used as the positive control for ampicillin-resistant $E$. coli strain while ampicillin was used in the case of kanamycin-resistant $E$. coli strain. Plates were incubated at $37^{\circ} \mathrm{C}$ for $18 \mathrm{~h}$ and an hour before the end of incubation, $40 \mu \ell$ of $0.2 \mathrm{mg} / \mathrm{ml}$ INT ( $p$-iodonitrotetrazolium salt) solution was added to each well. The lowest concentration indicating inhibition of growth was recorded as the MIC. This was indicated by the clear well after further incubation with INT as opposed to the pinkish colouration in growth wells.

Table 1 Selected plants investigated and their usage

\begin{tabular}{|c|c|c|c|}
\hline HERB & $\begin{array}{l}\text { LOCAL } \\
\text { NAME }\end{array}$ & PLANTPART & USES AND REFERENCE \\
\hline $\begin{array}{l}\text { Aloe arborescens Mill } \\
\text { ASHODELACEAE }\end{array}$ & $\begin{array}{l}\text { Ikhala } \\
\text { Inkalane } \\
\text { encane }(Z)\end{array}$ & Leaves & Leaf decoction for diarrhoea [13], effective burn treatment [14] \\
\hline $\begin{array}{l}\text { Aloe striatula } \\
\text { ASHODELACEAE }\end{array}$ & $\begin{array}{l}\text { Inkalana }(X) \\
\text { Intelezi }(\mathrm{Ng})\end{array}$ & Leaves & Leaf decoction for diarrhoea [13], purgative, expels worms \\
\hline $\begin{array}{l}\text { Cyathula uncinulata } \\
\text { AMARANTHACEAE }\end{array}$ & Isinama $(X)$ & Leaves & Leaf decoction for HIV treatment [13], stomach ailment \\
\hline $\begin{array}{l}\text { Eucomis autumnalis } \\
\text { HYACINTHACEAE }\end{array}$ & $\begin{array}{l}\text { Ubhulungu becanti }(X) \\
\text { Umathunga }(Z)\end{array}$ & Root & Decoctions of bulb and roots for coli, flatulence [15]. \\
\hline $\begin{array}{l}\text { Hypoxis latifolia } \\
\text { HYPOXIDACEAE }\end{array}$ & Ilabatheka $(X, Z)$ & Root & $\begin{array}{l}\text { Treat benign prostrate [16]; Headaches, dizziness, mental disorders, } \\
\text { HIV inflammation [17]; Boil ground dried tuber for diarrhoea. }\end{array}$ \\
\hline $\begin{array}{l}\text { Lantana camara } \\
\text { VERBENACEAE }\end{array}$ & $\begin{array}{l}\text { Ndzindzibila }(X) \\
\text { Ubuhobe besikhiwa (N) } \\
\text { Mbarapati }(\mathrm{S})\end{array}$ & $\begin{array}{l}\text { Leaves } \\
\text { Flower }\end{array}$ & $\begin{array}{l}\text { Leaf decoction for boosting immune system in HIV patients } \\
\text { [Nomvula Twaise, personal communication], antivirus [18], treatment of wound [19]. }\end{array}$ \\
\hline
\end{tabular}

N - Ndebele; Ng - Nguni; S - Shona; $\times$ - Xhosa; Z - Zulu. 


\section{Cytotoxicity assays}

The in vitro cytotoxicities of the selected herbs and solvent-solvent fractions on a human hepatoma cell line, (Huh-7), which was established from a hepatocellular carcinoma were examined using a modified MTT assay [21]. The Huh-7 was maintained at $-80^{\circ} \mathrm{C}$ in Dulbecco's Modified Eagle Medium (DMEM) and recovered from preservative by centrifugation. The pellet was re-suspended in fresh DMEM and cultured in a humidified atmosphere at $37^{\circ} \mathrm{C}$ using RPMI 1640 supplemented with $10 \%$ foetal bovine serum, $100 \mathrm{U} / \mathrm{m} \ell$ penicillin $\mathrm{G}$ and $100 \mathrm{ug} / \mathrm{ml}$ streptomycin and L-glutamine (Gibco BRL) in $5 \% \mathrm{CO}_{2}$ incubator (Thermo Fischer Scientific, Wakenyaku Co. Ltd, Japan). Cells were sub-cultured every 2 days after confluent growth was observed.

The MTT assay was carried out as follows. Briefly, the cells at a density of $1 \times 10^{4}$ per m $\ell$ were seeded in each well of a flat-bottom 96-well plate containing $100 \mu \ell$ of the growth medium. Cells were permitted to adhere for $24 \mathrm{~h}$, and then treated with various fractions at concentrations 0 , 1,10 and $100 \mu \mathrm{g} / \mathrm{ml}$ for $72 \mathrm{~h}$. After that, $20 \mu \ell$ of $5 \mathrm{mg} / \mathrm{ml}$ MTT in phosphate buffered saline (PBS) was added to each well and the plate was incubated for an additional $2 \mathrm{~h}$. The medium was discarded and the formazan blue, which formed in the cells, was dissolved with $100 \mu \ell$ MTT stop solution (Triton-X100-20 ml; Isopropyl alcohol-500 ml; $\mathrm{HCl}-2 \mathrm{ml}$ ). After incubation at $37^{\circ} \mathrm{C}$ for $10 \mathrm{~min}$, the absorbance of the dissolved solutions was detected at $490 \mathrm{~nm}$ on a microplate ELISA reader (Thermo Labsystems, Japan). Cytotoxicity was expressed as the concentration of extracts or fractions inhibiting cell growth by $50 \%\left(\mathrm{IC}_{50}\right)$. All tests and analyses were run in triplicate. Statistical analyses were carried out using MS Excel 2007.

\section{Results}

\section{Antibacterial activities}

Active antibacterial extracts were revealed as clear spots of inhibition of the growth of test organisms in microtitre wells. The pinkish contrasting wells of bacterial growth was indicative of non-cleavage of the tetrazolium salt to yield the pinkish or purplish formazan products [22]. The average MIC values of the plants extracts ranged from $0.27 \mathrm{mg} / \mathrm{ml}$ and $2.5 \mathrm{mg} / \mathrm{ml}$ after $24 \mathrm{~h}$ of incubation (Figure 1). The Ethyl acetate fraction of each type of plant was the most active fraction against the test bacteria. E. autumnalis had the least MIC $(0.27 \mathrm{mg} / \mathrm{ml})$ followed by $C$. uncinulata $(0.39 \mathrm{mg} / \mathrm{m} \ell)$ and thus demonstrated good antibacterial activities. The methanol extract of H. latifolia had the highest value of MIC $(2.5 \mathrm{mg} / \mathrm{ml})$.

\section{Cytotoxicities of methanol extract of plants extract and fractions}

The results of cytotoxicity assays of the extracts and fractions of the investigated plants on human hepatoma

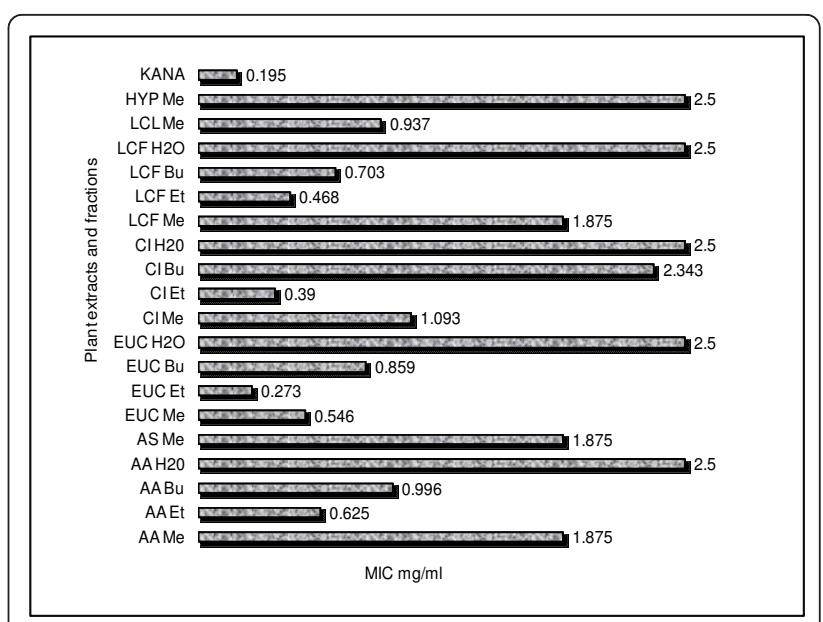

Figure 1 Minimum inhibitory concentration of plant extracts and fractions. $\mathrm{AA} M e=$ Methanol fraction of $A$. arborescens $(A A)$; $\mathrm{AA} E \mathrm{Et}=$ Ethyl acetate fraction of $\mathrm{AA} ; \mathrm{AA} B \mathrm{Bu}=\mathrm{n}$-Butanol fraction of $A A ; A A H 2 O=$ Water fraction of $A A ; A S M e=$ Methanol fraction of A. striata; EUC Me = Methanol fraction of $E$. autumnalis (EA); EUC Et $=$ Ethyl acetate fraction of EA; EUC Bu $=\mathrm{n}$-Butanol fraction of $E A$; EUC $\mathrm{H} 2 \mathrm{O}=$ Water fraction of $E A ; \mathrm{Cl} M e=$ Methanol fraction of $C$ uncinulata (CU); Et = Ethyl acetate fraction of $C U$; $C l B u=n-B u t a n o l$ fraction of $\mathrm{CU} ; \mathrm{Cl} \mathrm{H} 2 \mathrm{O}=$ Water fraction of $\mathrm{CU}$; LCF Me = Methanol fraction of $L$. camara fruit/flower (LCF); LCF Et = Ethyl acetate fraction of $L C F$; $L C F B u=n-B u t a n o l$ fraction of $L C F ; L C F H 2 O=L C F$ Water fraction of $L C F$; $L C L M e=$ Methanol fraction of $L$. camara leaves; HYP Me = HYP Methanol fraction.

cell line (Huh-7) are shown in Table 2. The methanol extract of E. autumnalis $\left(\mathrm{IC}_{50} 7.8 \mu \mathrm{g} / \mathrm{ml}\right)$ was more cytotoxic than the control toxic substance, berberine $\left(\mathrm{IC}_{50} 9.8 \mu \mathrm{g} / \mathrm{ml}\right)$, other plant extracts and solvent fractions. Of the solvent fractions, the Ethyl acetate and butanol fractions of $C$. uncinulata, $H$. latifolia, E. autumnalis and L. camara had moderate cytotoxic effects on the cancer cell lines tested with $\mathrm{IC}_{50}$ values ranging from 24.8 to $44.1 \mu \mathrm{g} / \mathrm{ml}$ while all the fractions of $A$. arborescens and $A$. striatula had insignificant or no cytotoxic effects after $72 \mathrm{~h}$ of treatment $\left(\mathrm{IC}_{50} 1000\right.$ to $>1000 \mu \mathrm{g} / \mathrm{ml}$ ).

\section{Discussion}

This study evaluated the cytotoxicity and antibacterial activities of methanol extracts and solvent fractions of A. arborescens, A. striatula, C. uncinulata, E. autumnalis, H. latifolia and L. camara. Among all the samples, the methanol extract of $E$. autumnalis exhibited greatest cytotoxicity on the cell line tested. However, the water fraction of E. autumnalis and that of other plants showed insignificant cytotoxicity on the cell line, compared with the polar solvent fractions (Table 2).

The Ethyl acetate fraction of E. autumnalis had the least MIC $(0.27 \mathrm{mg} / \mathrm{ml})$ followed by C. uncinulata $(0.39$ $\mathrm{mg} / \mathrm{m} \ell$ ) against the test bacteria and thus demonstrated 


\begin{tabular}{|c|c|c|c|}
\hline $\begin{array}{l}\text { CODE } \\
\text { S/NO }\end{array}$ & $\begin{array}{l}\text { SAMPLE } \\
\text { CODE }\end{array}$ & EXTRACT FRACTION & $\mathrm{IC}_{50}(\mathrm{ug} / \mathrm{ml})$ \\
\hline 1 & AA Me & AA Methanol fraction & $>1000$ \\
\hline 2 & AA Et & AA Ethyl acetate fraction & $>1000$ \\
\hline 3 & $\mathrm{AA} \mathrm{Bu}$ & AA n-Butanol fraction & $>1000$ \\
\hline 4 & $\mathrm{AA} \mathrm{H} 2 \mathrm{O}$ & AA Water fraction & $>1000$ \\
\hline 5 & AS Me & AS Methanol fraction & 1000 \\
\hline 6 & EUC Me & EA Methanol fraction & 7.8 \\
\hline 7 & EUC Et & EA Ethyl acetate fraction & 28.5 \\
\hline 8 & EUC Bu & EA n-Butanol fraction & 39.3 \\
\hline 9 & $\mathrm{EUC} \mathrm{H} 2 \mathrm{O}$ & EA Water fraction & 379.0 \\
\hline 10 & $\mathrm{Cl} \mathrm{Me}$ & Cl Methanol fraction & 24.8 \\
\hline 11 & $\mathrm{Cl} \mathrm{Et}$ & $\mathrm{Cl}$ Ethyl acetate fraction & 36.3 \\
\hline 12 & $\mathrm{Cl} \mathrm{Bu}$ & $\mathrm{Cl}$ n-Butanol fraction & 30.0 \\
\hline 13 & $\mathrm{Cl} \mathrm{H} 2 \mathrm{O}$ & Cl Water fraction & 714.0 \\
\hline 14 & LCF Me & LCF Methanol fraction & 169.0 \\
\hline 15 & LCF Et & LCF Ethyl acetate fraction & 44.1 \\
\hline 16 & LCF Bu & LCF n-Butanol fraction & 150.0 \\
\hline 17 & LCF H2O & LCF Water fraction & 1000 \\
\hline 18 & LCL Me & LCL Methanol fraction & 161.0 \\
\hline 19 & HYP Me & HYP Methanol fraction & 24.4 \\
\hline$P C$ & Positive control & Berberine & 9.8 \\
\hline
\end{tabular}

AA - Aloe arborescens; AS - Aloe striatula; EA - Eucomis autumnalis; Cl Cyathula uncinulata; LCF - Lantana camara (flower/fruits); LCL - Lantana camara (leaves); HYP - Hypoxis latifolia.

good antibacterial activities. Various biological activities of Eucomis were reported [23,24]. E. autumnalis is known for its anti-inflammatory and antispasmodic activities and these have been attributed to components such as homoisoflavones and flavonoids [25]. E. autumnalis also contains some steroidal triterpenoids which are known to be beneficial in wound therapy [25]. However, the bulb was reported to be toxic [25] agreeing very much with our findings.

Eucosterol glycoside, a lanosterol oligosaccharides isolated from $E$. bicolor demonstrated antitumor activity by causing $44 \%$ inhibition of TPA-stimulated ${ }^{32} \mathrm{P}$ incorporation into phospholipids of HeLa. This activity has been suggested to probably relate to the use of bulb decoctions of E. autumnalis to relieve abdominal distensions and abdominal pain by the Tswana and Pedi tribes of South Africa [26]. According to Koorbanally et al. [27], sheep drenched with fresh bulbs of E. autumnalis in an animal feeding trial presented with listlessness, anorexia, foaming at the mouth, tympanites, an inactive rumen and a strong pulse leading eventually to death within twentyfour hours. Despite these submissions Eucomis is one of the most traded genera of plants in South Africa [28], hence the need for caution in their usage.

\section{Conclusions}

In conclusion, the results obtained indicated that the methanol extract of E. autumnalis exhibited much greater cytotoxicity than the methanol extract and solvent fractions of all other plants investigated even though it had strong antibacterial activities. E. autumnalis showed selective anticancer activity against the human hepatoma cell line, whereas the two Aloe spp. were non toxic on the cell line. In addition, the study showed that Aloe arborescens, A. striatula and C. uncinulata may be candidate plants for eventual drug design. Medicinal plants are natural products and may have therapeutic potentials; however, being natural does not make them automatically safe.

\section{Acknowledgements}

This study was supported by the Institutional Research Grant of Walter Sisulu University (WSU), the National Research Foundation (NRF) grant awarded under the aegis of the South Africa - Japan Research Collaborative Agreement and the Focus Area Grant of the NRF. Our profound gratitude goes to the traditional healers and the locals for sharing their folk knowledge on the plants studied. We also appreciate the technical support of Asai Teigo of the Natural Products Chemistry, School of Pharmacy, Tohoku University, Obayama, Sendai, Japan and David Wopula of WSU Botany Department for sourcing of plant materials. Ms Nomvula Twaise (Director, WSU HIV/AIDS Centre) is acknowledged for her useful information on L. camara. The general support obtained from the Department of Medical Microbiology, WSU, and the Phytomedicine group, Department of Paraclinical Science, University of Pretoria is worthy of appreciation.

\section{Author details}

'Department of Medical Microbiology, Walter Sisulu University, Mthatha 5117, South Africa. ${ }^{2}$ Division of Academic Affairs \& Research, Walter Sisulu University, Mthatha 5117, South Africa. ${ }^{3}$ Department of Emerging Infectious Diseases, School of Medicine, Postgraduate Division, Tohoku University, Sendai, Japan. ${ }^{4}$ Department of Natural Products Chemistry, Graduate School of Pharmaceutical Sciences, Tohoku University, Sendai, Japan. ${ }^{5}$ Department of Botany, Walter Sisulu University, Mthatha 5117, South Africa.

${ }^{6}$ Phytomedicine Programme, Department of Paraclinical Science, Faculty of Veterinary Medicine, University of Pretoria, Onderstepoort 0110, South Africa.

\section{Authors' contributions}

MAB participated in the design of the study, carried out field work, prepared the extracts, participated in the MTT assay and drafted the manuscript. CLO conceived of the study, participated in the design and coordination of the study, supervised the study and revised the manuscript. TH coordinated bench work between collaborators in South Africa and Japan and helped to revise the manuscript. YO was involved in coordination of study done in Japan. SL was involved in cell culturing, MTT assay and statistical analysis. LK coordinated field work and plant sourcing. JNE was involved in coordination and helped to revise the manuscript. SDV assisted with the concept and design of the study and provided technical advice. Authors read and approved the final manuscript.

\section{Competing interests}

The authors declare that they have no competing interests.

Received: 10 September 2010 Accepted: 17 February 2011 Published: 17 February 2011

\section{References}

1. McGaw LJ, Jager AK, van Steden J: Antibacterial, antihelmintic and antiamoebic activity in South African medicinal plants. J Ethnopharmacol 2000, 72:247-63. 
2. Vieira RHS, Rodrigues D, Goncalves FA, Menezes FGR, Aragao JS, Sousa OV: Microbicidal effect of medicinal plant extracts (Psidium guajava Linn. and Carica papaya Linn.) upon bacteria isolated from fish muscle and known to induce diarrhoea in children. Rev do Instituto de Med Tropical de Sao Paulo 2001, 43:145-148.

3. Samie A, Obi CL, Bessong PO, Namrita L: Activity profiles of fourteen selected medicinal plants from Rural Venda communities in South Africa against fifteen clinical bacterial species. Afr J Biotechnol 2005, 4:1443-1451.

4. Smolinske SC: DABAT Herbal Product Contamination and Toxicity. J Pharm Pract 2005, 18:188-208.

5. Luyckx VA, Naicker S: Acute kidney injury associated with the use of traditional medicines. Nat Rev Nephrol 2008, 4:664-671.

6. Foyaca-Sibat $H$, Ibañéz $V$, Awotedu AA: Acute renal failure due to herbal medicine intoxication in acquired neuromyotonia. [http://www.uninet. edu/cin2001-old/paper/ibanez/foyaca.html], Accessed May 20, 2010.

7. McGaw LJ, Steenkamp V, Eloff JN: Evaluation of Athrixia bush tea for cytotoxicity, antioxidant activity, caffeine content and presence of pyrrolizidine alkaloids. J Ethnopharmacol 2007, 110:16-22.

8. Aderogba MA, McGaw $\perp$, Ogundaini AO, Eloff JN: Antioxidant activity and cytotoxicity study of the flavonol glycosides from Bauhinia galpinii. Nat Prod Res 2007, 21:591-599.

9. Elgorashi EE, Taylor JLS, Verschaeve L, Maes A, van Staden J, De Kimpe N: Screening of medicinal plants used in South African traditional medicine for genotoxic effects. Toxicol Letters 2003, 143:195-207.

10. Boyd MR, Hallock YF, Cardellina JH, Manfredi KP, Blint JW, McMahon JB, et al: Anti-HIV michellamines from Ancistrocladus korupensis. J Med Chem 1994, 37:1740-1745.

11. Neuwinger HD: African Traditional Medicine. A Dictionary of Plant Use and Applications. Medpharm Scientific Publishers, Stuttgart; 2000, ISBN 388763-086-6.

12. Oshima Y, Cordell GA, Fong HSHarry: Studies on Zoapatle, III. Flavonoid Glycosides from Montanoa tomentosa ssp. Tomentosa. J Nat Prod 1986, 49:552-553.

13. Bisi-Johnson MA, Obi CL, Kambizi L, Nkomo M: A survey of indigenous herbal diarrhoeal remedies of O.R. Tambo district, Eastern Cape Province, South Africa. Afr J Biotechnol 2010, 9:1245-1254.

14. Pooley E: The Complete Field Guide to Trees of Natal Zululand and Transkei. Natal Flora Publication Trust. C/o Natal Herbarium Botanic Gardens Road, Durban 4001, 1 1993, 512.

15. Cunningham AB: Ethics, ethnobiological research and biodervisty. WWFWorld Wide Fund for Nature (formerly World Wildlife Fund), Gland, Switzerland; 1993.

16. van Staden J: Constituents of Hypoxis rooperi, a valuable medicinal plant in South Africa. Deutsche Apotheke Zeitung 1981, 33:460-464.

17. Van Wyk BE, Gericke N: People's Plants: A Guide to Useful Plants of Southern Africa. Briza Publications, Pretoria; 2000, ISBN 978-1-875093-19-9.

18. Inada A, Nakanish T, Tokuda H, Nishino H, Iwasma A, Sharma OP: Inhibitory effects of lantadenes and related triterpenoids on Epstein-Barr virus activation. Planta Med 1995, 61:558-559.

19. Abdulla MA, Hassandarvish P, Ali HM, Noor SM, Mahmoud FH, Bashah NSA, et al: Acceleration of wound healing potential by Lantana camara leaf extract in experimental rats. Res J Med Sci 2009, 3:75-79.

20. Eloff $J \mathrm{~N}$ : A sensitive and quick method to determine the minimum inhibitory concentration of plant extracts for bacteria. Planta Medica 1998, 60:1-8.

21. Plumb JA, Milroy R, Kaye SB: Effects of the $\mathrm{pH}$ dependence of 3-(4, 5dimethylthiazol-2-yl)-2, 5-diphenyltetrazolium bromide-formazan absorption on chemosensitivity determined by a novel tetrazoliumbased assay. Cancer Res 1989, 49:4435-4440.

22. Begue WJ, Kline RM: The use of tetrazolium salts in bioautographic procedures. J Chromatography 1972, 64:182-184.

23. Du Toit K, Elgorashi E, Malan SF, Drewes SE, van Staden J, Crouch NR, Mulholland DA: Anti-inflammatory activity and QSAR studies of compounds isolated from Hyacinthaceae species and Tachiadenus longiflorus Griseb. (Gentianaceae). J Bioorganic Med Chem 2005, 13:2561-2568.

24. Gaidamashvili M, van Staden J: Prostaglandin inhibitory activity by lectinlike proteins from South African medicinal plants. S Afr J Bot 2006, 72:661-663.
25. Notten A, Kirstenbosch NBG: Eucomis autumnalis (Mill.) Chitt Family: Hyacinthaceae (Hyacinth Family). 2002 [http://www.plantzafrica.com/ frames/plantsfram.htm].

26. Watt JM, Breyer-Brandwijk MG: The medicinal and poisonous plants of southern and eastern Africa. E. \&S. Livingstone Ltd., Edinburgh and London; 1962.

27. Koorbanally C, Crouch NR, Mulholland DA: The phytochemistry and ethnobotany of the southern African genus Eucomis (Hyacinthaceae: Hyacinthoideae). Phytochemistry: Advances in Res 2006, 69-85, ISBN: 81-3080034-9.

28. Dold AP, Cocks ML: The trade in medicinal plants in the Eastern Cape Province, South Africa. S Afr J Sci 2002, 98:589-597.

\section{Pre-publication history}

The pre-publication history for this paper can be accessed here: http://www.biomedcentral.com/1472-6882/11/14/prepub

doi:10.1186/1472-6882-11-14

Cite this article as: Bisi-Johnson et al:: Evaluation of the antibacterial and anticancer activities of some South African medicinal plants. BMC Complementary and Alternative Medicine 2011 11:14.

\section{Submit your next manuscript to BioMed Central and take full advantage of:}

- Convenient online submission

- Thorough peer review

- No space constraints or color figure charges

- Immediate publication on acceptance

- Inclusion in PubMed, CAS, Scopus and Google Scholar

- Research which is freely available for redistribution

Submit your manuscript at www.biomedcentral.com/submit 